\title{
Correction to: The Eye of a Needle: Temporary Prison Leave in Ukraine
}

\author{
Anton Symkovych ${ }^{1,2}$ \\ Published online: 5 June 2020 \\ (C) The Author(s) 2020
}

\section{Correction to: European Journal on Criminal Policy and Research https://doi.org/10.1007/s10610-019-09433-3}

The article The Eye of a Needle: Temporary Prison Leave in Ukraine, written by Anton Symkovych, was originally published electronically on the publisher's internet portal on $\mathbf{2 8}$ December 2019 without open access.

With the author(s)' decision to opt for Open Choice the copyright of the article changed on 01 June 2020 to (C) The Author(s) 2020 and the article is forthwith distributed under a Creative Commons Attribution 4.0 International License (https://creativecommons.org/licenses/by/4.0/), which permits use, sharing, adaptation, distribution and reproduction in any medium or format, as long as you give appropriate credit to the original author(s) and the source, provide a link to the Creative Commons licence, and indicate if changes were made.

The original article has been corrected.

Open Access This article is licensed under a Creative Commons Attribution 4.0 International License, which permits use, sharing, adaptation, distribution and reproduction in any medium or format, as long as you give appropriate credit to the original author(s) and the source, provide a link to the Creative Commons licence, and indicate if changes were made. The images or other third party material in this article are included in the article's Creative Commons licence, unless indicated otherwise in a credit line to the material. If material is not included in the article's Creative Commons licence and your intended use is not permitted by statutory regulation or exceeds the permitted use, you will need to obtain permission directly from the copyright holder. To view a copy of this licence, visit http://creativecommons.org/licenses/by/4.0/.

Publisher's Note Springer Nature remains neutral with regard to jurisdictional claims in published maps and institutional affiliations.

The online version of the original article can be found at https://doi.org/10.1007/s10610-019-09433-3

Anton Symkovych

anton.symkovych@unimelb.edu.au

1 School of Social and Political Sciences, The University of Melbourne, Melbourne, Australia

2 Department of Sociology, University of Johannesburg, Johannesburg, South Africa 